\title{
SNOW STABILITY INDEX
}

\section{By H. Conway and J. Abrahamson}

(Department of Chemical and Process Engineering, University of Canterbury, Private Bag, Christchurch, New Zealand)

\begin{abstract}
Field tests have been developed to measure the shear and tensile strengths of large volumes of snow. Basal shear strengths were measured across and down some slabs of snow, giving highly variable strengths. These measurements support the idea that the basal region of an avalanche may contain zones where the basal shear strength exceeded the gravitational shear stress (i.e. pinning areas) with weak zones between (deficit areas) where the shear strength was less than the gravitational shear stress. The slab tensile stresses induced by these deficit areas would become high if either the deficit length (down-slope) was large, or the deficit itself was large. Measurements of tensile strengths of slabs above weak layers, together with the down-slope gravitational stress of a snow slab, suggest that deficit lengths of only several metres are often sufficient to cause a local tensile failure. In some cases, this tocal failure may propagate across the remainder of the slope (depending on the pinning distribution) and cause an avalanche. We propose that the maximum local deficit, rather than the mean slope deficit of basal shear stress, and the maximum length of the local deficit, are the first important parameters to consider when evaluating slope stability in the field, since the magnitude of these factors determine the probability of a local tensile failure.
\end{abstract}

RÉsumé. Indicateur de stabilité de la neige. Des tests de terrain ont été développés pour la mesure des limites de cisaillement et de tension pour de grands volumes de neige. Des limites de cisaillement à la base ont été mesurés transversalement et longitudinalement pour des couvertures de neige, conduisant à des efforts hautement variables. Ces mesures confortent l'idée que la région basale d'une avalanche peut contenir des zones où l'effort limite de cisaillement à la base dépasse la contrainte de cisaillement de gravité (c'est-à-dire les zones en butée) intercalées avec des zones de faiblesse (zones de déficit) où l'effort de cisaillement limite est inférieur à la contrainte de cisaillement due au poids. Les contraintes de traction dans la couche, créées par ces zones dé déficit, peuvent prendre des valeurs élevées soit parce que les longueurs (selon la pente) où s'exerce ce déficit sont étendues, soit parce que le déficit lui-mème est important. Des mesures de limite de rupture en traction pour des plaques au-dessus de couches faibles, en même temps que

\section{INTRODUCTION}

Most slab failure models assume a weak basal layer (Perla, 1980), and a shear frame first used by Roch (1966) has been used by many to study this layer. Variations of a "shear index" (i.e. the ratio of the shear strength of a snow layer, measured with a shear frame, to the gravitational shear stress) in the basal zones of avalanches have been previously documented and mainly attributed to either the small size of the shear frame used (Sommerfeld, 1973, 1980; Perla, 1977; Sommerfeld and King, 1979) or test-rate effects (McClung, 1977, 1979; Perla and others, 1982; Montmollin, 1982). In this paper, we report on basal shear measurements made with larger basal test areas, and series of measurements made across slopes and down slopes.

Perla and LaChapelle (1970) derive equations to estimate the tensile stress $t_{x x}$ induced by a shear perturbation (supepimposed on the infinite slab situation) in the basal zone:

$$
t_{x x}=(x / Z) \pi x z
$$

where $t_{x x}$ is the order of magnitude of the induced tensile stress in the $x$ direction (down-slope), $\pi x z$ is the basal perturbation of shear stress, $2 x$ is the length of the perturbation, and $Z$ is the depth of the slab.

Equation (1) shows that an index relating basal weakness to tensile failure should include not only the magnitude of the weakness, but also the length des mesures de contraintes de pesanteur pour une plaque de neige, suggèrent que les longueurs de déficit de quelques mètres seulement sont suffisantes pour créer une rupture locale en traction. Dans certains cas, cette rupture locale peut se propager à travers le reste de la pente (suivant la concentration des contraintes) et être la cause d'une avalanche. Nous proposons que le maximum du déficit local, plutôt que la moyenne du déficit de la contrainte de cisaillement pour toute la pente, et que le maximum de longueur du déficit local, soient les premiers des paramètres importants à prendre en considération pour évaluer la stabilité de la pente puisque l'amplitude de ces facteurs détermine la probabilité d'une rupture locale en traction.

Zusammenfassung. Index für die Schnee-Stabilität. Zur Messung der Scherund Zugfestigkeit grosser Schneepakete wurden Feldprüfverfahren entwickelt. Die Scherfestigkeit am Untergrund wurde an einigen Schneeplatten quer und längs gemessen, wobei sich sehr unterschiedliche Werte ergaben. Diese Messungen stützen die Annahme, dass der untere Teil einer Lawine Zonen enthalten dürfte, wo die Scherfestigkeit die Scherspannung infolge der Schwerkraft übertrifft (sog. Haftgebiete), mit Schwächezonen (Defizitgebieten) dazwischen, wo die Scherfestigkeit geringer ist als die Scherspannung infolge der Schwerkraft. Die Zugspannungen in der Platte, verursacht durch diese Defizitgebiete, würden hoch werden, wenn entweder die Defizitlänge (hangabwärts) oder das Defizit selbst gross ist. Messungen der Zugfestigkeit von Platten über schwachen Schichten, kombiniert mit der hangabwärts gerichteten Schwerkraftspannung einer Schneeplatte, lassen vermuten, dass Defizitlängen von nur einigen Metern oft genügen, um lokal einen Bruch infolge des Zuges zu verursachen. In einigen Fällen kann sich dieser lokale Bruch über den ganzen Hang fortpflanzen (in Abhängigkeit von der Verteilung der Haftkräfte) und eine Lawine auslösen. Wir schlagen vor, dass anstelle des mittleren Defizits der basalen Scherspannung am Hang das maximale lokale Defizit und die maximale Länge desselben als Hauptparameter bei der Abschätzung der Hangstabilität im Feld herangezogen werden, da die Grösse dieser Faktoren die Wahrscheinlichkeit eine lokalen Zugbruches bestimmen.

over which the perturbation exists (2x), the slab thickness $(Z)$ and the tensile strength of the slab. When a weak zone is large, or the shear strength is small, high stresses are induced in the slab which could promote local failure.

Once a slope has failed locally, propagation of the failure would depend upon the distribution of stresses and strengths at the boundaries of the local failure. Zones of high strength (pinning areas) may inhibit propagation, but conditions may effectively cause the removal of the pinning areas and result in widespread failure.

In a similar model, Stuiver and others (1981) propose that the West Antarctic ice sheet is pinned at various boundary zones, and they use a computer model to consider the effects of removal of various pinning areas. Chowdhury and A-Grivas (1982) deal with this problem using a probabilistic model. For a soil slope, they consider the probable distribution of the shearstrength/shear-stress ratio, and the interaction between adjacent elements, to determine the probability of crack progression.

\section{FIELD STUDIES}

To study local shear strengths at basal zones, we embedded a large shear frame (which had dimensions $300 \mathrm{~mm} \times 300 \mathrm{~mm} \times 50 \mathrm{~mm}$ and weighed $1 \mathrm{~kg}$ ) on the snow surface. With a saw, we cut out a column around the frame to isolate the block from effects of side shear and compressive and tensile hold-up, to a depth greater than the suspected fracture plane. It was found 
that embedding the frame before isolating the column reduced disturbance of the sample. A slope-parallel pull was applied to the frame with a calibrated spring until failure occurred somewhere down the column. We noted the surface area of the fracture, the depth of the fracture, slab density, and the bed surface angle. These measurements made it possible for us to calculate the gravity component of stress parallel to the slope. The sum of this and the measured force to failure, divided by the shear area, gave the shear strength (see Figure 1).

\section{$300 \times 300 \times 50 \mathrm{~mm}$}

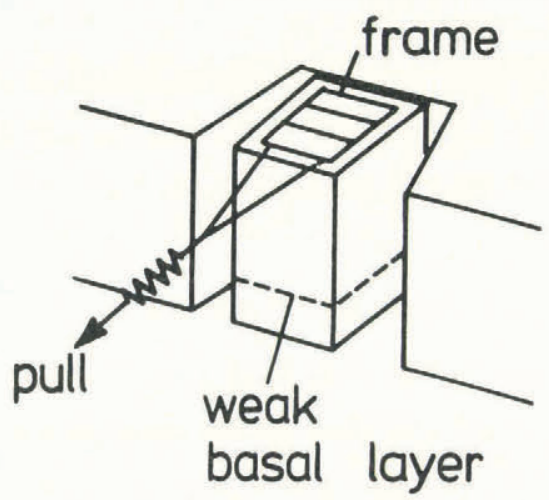

Fig. 1. Shear-test measurements at the weakest basal layer. The weak layer was at a depth $z$ from the surface and the average density $\rho$ of the snow above the weak layer was measured. The bed surface angle $\theta$ and the force $F_{8}$ in the down-slope $x$ direction required to fracture the column were measured. Typical shear areas $A_{s}$ over which the force was applied were about $0.15 \mathrm{~m}^{2}$.

In cases where the shear strength of the basal layer was small compared with the "ploughing strength" of the surface snow from which the frame was being pulled, the column sheared before the frame ploughed through the surface snow. In situations where the surface snow was weak, we re-embedded the frame in a lower layer and repeated the test.

This test has several advantages over the traditional shear-frame test:

(1) The weakest sliding layer did not need to be precisely located before the test and detailed analysis of the snow stratigraphy above the shear layer was not necessary.

(2) The normal loading over the shear layer was retained during the test.

(3) Disturbance of the weak layer when placing the frame was minimized.

The disadvantage of this test was the possibility of a bending mode of failure, and we noticed this especially with deep columns (depth greater than about $1.5 \mathrm{~m}$ ) with no well-defined, low-strength sliding layer. In these cases, applied stresses were high (about $4000 \mathrm{~N} / \mathrm{m}^{2}$ ) and the yield surface was often stepped. To eliminate some of the bending moment, we built a frame which could be inserted just above the suspected shear layer. This shear frame was similar to our other frame, but had one side which could be detached, which enabled it to be inserted from one side of the column just above the suspect layer. The other (detachable) side could then be attached to the frame and a force applied to the column. This frame was not as easy nor as fast to use as the frame placed on the snow surface.

Testing times for the application of load were of the order of 0 to $5 \mathrm{~s}$ to failure, but our control of the instantaneous rate of loading was poor. However, a simple local basal shear stability index $\alpha$ could be computed from the ratio of the local shear strength to the gravitational shear stress

$$
\alpha=\left(F_{S} / A_{S}+\bar{\rho}^{\prime} g z^{\prime} \sin \theta\right) /(\bar{\rho} g z \sin \theta)
$$

where $F_{S}$ is the applied force required to shear the column, As the shear area over which the force is applied, $\vec{p}$ the mean slab density, $g$ the gravitational acceleration, $z^{\prime}$ the depth of snow above the fracture plane when the test was made (with a corresponding $\rho$, as the mean snow density of the snow to depth $z^{\prime}$ ), $z$ the depth to the fracture plane from the snow surface, and $\theta$ the bed surface angle. By weighing a small column and dividing by the shear area, we could often measure the product of the mean slab density $(\bar{p})$ and depth $(z)$ directly. Columns that slid before they could be completely isolated were assigned an index $(\alpha)$ of less than 1 .

Once the weak layer had been identified, we made tensile tests of the slab above this layer. We isolated a column from effects of side shear and compressive hold-up with a saw, and inserted one of the frames described above on each side of the sample (as shown in Figure 2). The frames were linked to a rod which also had a calibrated spring attached. We then slid a stiff and essentially frictionless stainlesssteel plate up the weak layer to remove basal shear

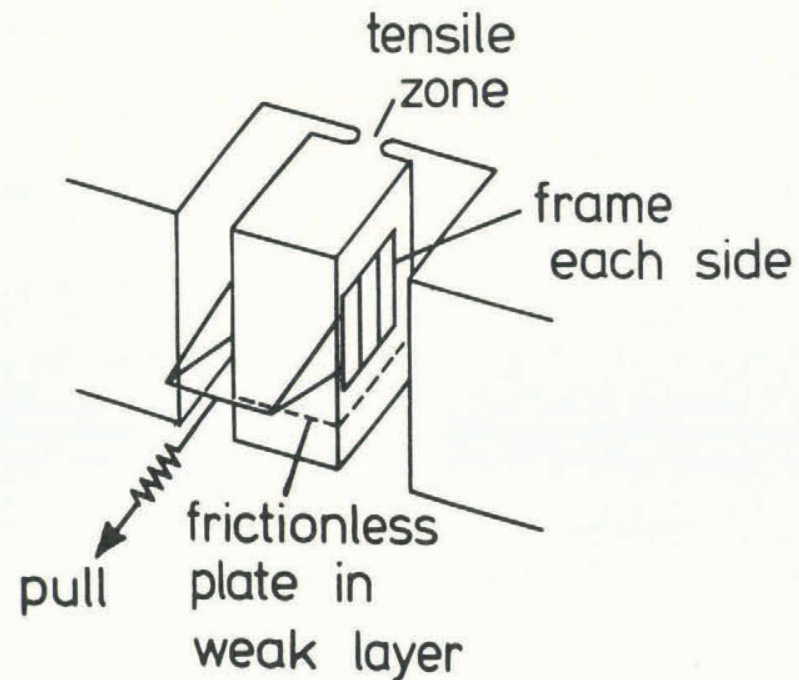

Fig. 2. Tensile tests of a slab above a weak layer. The scooped shape in the tensile zone helped relieve stress concentration in that area ( $A_{T}$ ) which was typically about $0.1 \mathrm{~m}^{2}$ in these tests. The frictionless plate had been inserted at a depth $z$ from the surface at an angle of $\Theta$ to the horizontal in the up-slope direction. The pull $F_{T}$ required in the down-slope $(x)$ direction was measured.

support, and used a scoop at the tensile zone to reduce the cross-sectional area and hence the force required to fracture the sample. Also, rounding off the cut oy the scoop relieved stress concentrations. Again rate control was poor but tests were generally over a time of 0 to.15 s to fracture. The area of fracture was usually about $0.1 \mathrm{~m}^{2}$. The force applied to fracture the column, together with measurements of slab density, bed surface angle, and area of fracture, enabled us to calculate a tensile strength $\sigma \mathrm{T}$ of the slab:

$$
\sigma_{T}=\left(F_{T}+\bar{\rho} g z a b \sin \theta\right) / A_{T}
$$

where $F_{T}$ is the applied force required to fracture the column in tension, AT the area of tensile failure, and $a b z$ is the snow column volume.

If the shear stress on the weakest basal layer in a snow pack exceeds its shear strength (locally) we have a deficit, or lack of support $\pi x z$. Ignoring side-shear support, $\pi x z$ is taken here to be the difference between the gravitational shear stress and 
the local shear strength. By combining Equation (1) and Equation (2) and substituting for $\pi x z$ (assuming $\bar{\rho}=\bar{\rho}^{\prime}$ and $z=z^{\prime}$ ), the induced tensile stress is given by

$$
t_{x x}=x(1-\alpha) \bar{p} g \sin \theta \text {. }
$$

This stress approaches or exceeds the tensile strength as $\alpha$ approaches zero and/or $X$ becomes larger. In fact, for zero shear strength over a slab length of $2 x$, (in which case $\alpha=0$ ), and where $X$ is sufficiently large $\left(X_{c}\right)$ so that the induced tensile stress equals or exceeds the tensile strength $\left(t_{x x}>\sigma_{T}\right)$, then

$$
X_{C}=\sigma T / \bar{\rho} g \sin \theta
$$

Brown and others (1972) also use this simple model (considering the influence of Poisson effects to be smal1) to give a measure of the critical deficit length $2 x_{0}$ in the direction of the slope. We have used Equation (5) to calculate appropriate values of $X_{C}$ from our $\sigma_{T}$ measurements.

\section{FIELD AREA}

We made the field measurements reported below on slopes around the upper Tasman Glacier $(2100 \mathrm{~m})$ in the Mount Cook National Park over the New Zealand 1981 and 1982 winters. This is a region of high snowfall, where storm cycles may typically deposit 0.3 $1.5 \mathrm{~m}$ of dry snow with a density range of 40 to 250 $\mathrm{kg} / \mathrm{m}^{3}$. Winter snow-pack temperatures may vary from $-2^{\circ} \mathrm{C}$ to $-25^{\circ} \mathrm{C}$, and most slopes have a glacial base. The area is noted for considerable wind strength and most snow-falls are associated with wind.

\section{SUMMARY OF FIELD MEASUREMENTS}

Shear indices measured on the crown walls of eight avalanched slopes yielded a total of 93 values of $\alpha$, which had a mean and standard deviation of 1.57 and 1.29 respectively, with a range of $6.82>\alpha>0$. For comparison, 18 slopes which had not fractured (63 measurements) gave values for $\alpha$ mean and standard deviation of 4.25 and 2.78 respectively with a range of $13.3>\alpha>0$.

Figure 3 shows, for all the above slopes, a plot of the smallest measured $\alpha$ against the longest length over which this smallest $\alpha$ was found. Where multiple

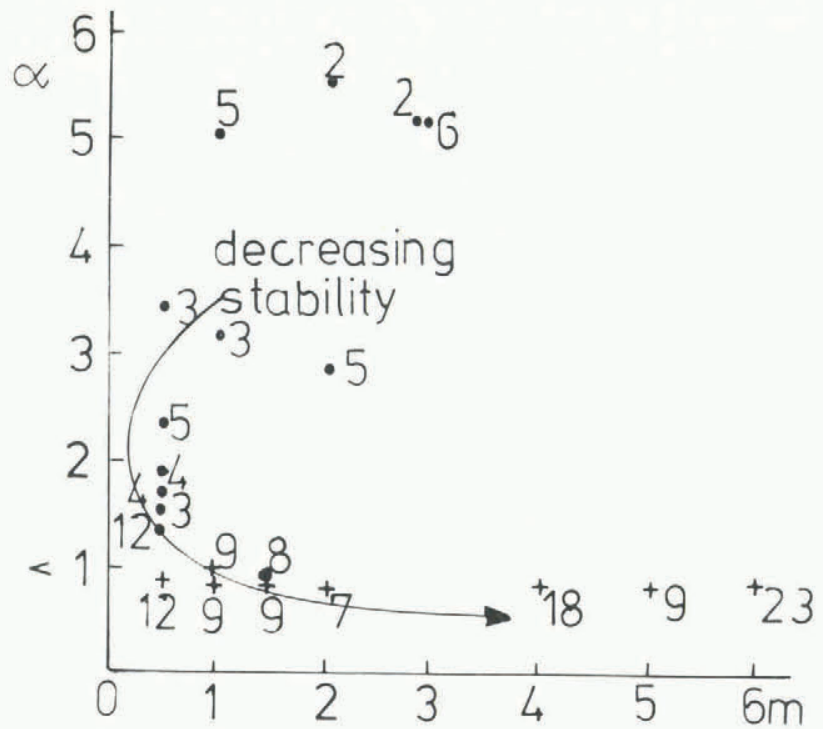

Fig. 3. Plot of the minimum shear index measured on each slope against the maximum length of this weakest zone measured on each slope. The total number of tests on each slope is listed beside each point (+ denotes measurements made on slopes that had avalanched, - denotes measurements made on slopes that had not avalanched).

tests (about 0.5 to $1 \mathrm{~m}$ apart) were made across, rather than down slopes, we included these in our plot also. Figure 3 shows a distinction between fractured and unfractured slopes, in that for all the fractured slopes, at least one value of the index $\alpha$ was less than 1. Most slabs that had not avalanched had a minimum shear index greater than 1. One unfractured slope did have an index less than 1. Slopes adjacent to this particular slope, and of similar aspect, had aval anched.

Table I lists tensile-type measurements made on various slopes, including the minimum and mean $X_{C}$ evaluated from Equation (5) (using tensile strengths

\begin{tabular}{|c|c|c|c|c|c|c|c|c|c|}
\hline $\begin{array}{l}\text { State of } \\
\text { slope }\end{array}$ & $\begin{array}{c}\text { Bed surface } \\
\text { angle } \\
\text { deg }\end{array}$ & $\begin{array}{c}\text { Mean slab } \\
\text { density } \\
\mathrm{kg} / \mathrm{m}^{3}\end{array}$ & $\begin{array}{l}\text { No. of } \\
\text { tensile } \\
\text { measurements }\end{array}$ & $\begin{array}{c}\text { Mean tensize } \\
\text { strength } \\
\mathrm{N} / \mathrm{m}^{2}\end{array}$ & $\begin{array}{c}\text { Minimum } \\
x_{c} \\
m\end{array}$ & $\begin{array}{c}\text { Mean } \\
X_{c} \\
m\end{array}$ & $\begin{array}{l}\text { Minimum a } \\
\text { measured }\end{array}$ & $\begin{array}{c}\text { Minimum shear } \\
\text { strength } \\
\mathrm{N} / \mathrm{m}^{2}\end{array}$ & $\begin{array}{l}\text { Maximum } \\
\text { When } \\
\alpha<1\end{array}$ \\
\hline$n f$ & 28 & 185 & 4 & 1342 & 1.13 & 1.58 & 2.70 & 780 & \\
\hline$n f$ & 35 & 236 & 1 & 3450 & 2.60 & 2.60 & 3.46 & 1100 & \\
\hline$n f$ & 43 & 160 & 2 & 1965 & 1.46 & 1.80 & 1.77 & 635 & \\
\hline$n f$ & 33 & 200 & 2 & 8770 & 5.94 & 8.22 & $<1$ & $<1110$ & 0.75 \\
\hline$n f$ & 33 & 244 & 2 & 2670 & 1.95 & 2.05 & 2.85 & 1675 & \\
\hline$n f$ & 43 & 224 & 2 & 2937 & 1.93 & 1.96 & 2.33 & 1400 & \\
\hline$n f$ & 38 & 227 & 4 & 5386 & 2.34 & 3.93 & 7.8 & 3220 & \\
\hline is & 30 & 90 & 2 & 84 & 0.17 & 0.21 & - & 114 & \\
\hline $1 \mathrm{~s}$ & 29 & 160 & 2 & 370 & 0.36 & 0.49 & - & 380 & \\
\hline is & 35 & 60 & 3 & 318 & 0.63 & 0.94 & - & 213 & \\
\hline ls & 40 & 60 & 2 & 113 & 0.25 & 0.30 & - & 10 & \\
\hline SS & 47 & 140 & 3 & 1073 & 0.68 & 1.07 & $<1$ & $<320$ & 1.0 \\
\hline ss & 30 & 212 & 1 & 2320 & 2.23 & 2.23 & $<1$ & $<620$ & 1.0 \\
\hline hs & 35 & 250 & 2 & 15050 & 10.25 & 10.71 & $<1$ & $<1320$ & 0.75 \\
\hline
\end{tabular}

TABLE I. TENSILE-TYPE MEASUREMENTS FOR SNOW SLOPES

where: $n f=$ not fractured

$1 \mathrm{~s}=100 \mathrm{se}$ slide

ss $=$ soft slab

hs $=$ hard slab 
calculated from Equation (3). On slopes where $\alpha<1$, half the maximum length (maximum $X$ ) containing this weakness is also listed in Table I.

\section{BASAL PINNING MEASUREMENTS}

Two examples of basal strength variations found on fractured slopes are shown in Figure 4 (across a crown wall) and Figure 5 (down a flank wall).

The fracture of 13 July 1982 (Figure 4) shows a variable crown-wall depth, ranging from 0.32 to $0.54 \mathrm{~m}$. In some places, we observed a second shear layer above the bed surface, and this also is plotted in Figure 4 . The avalanche had been ski-released near

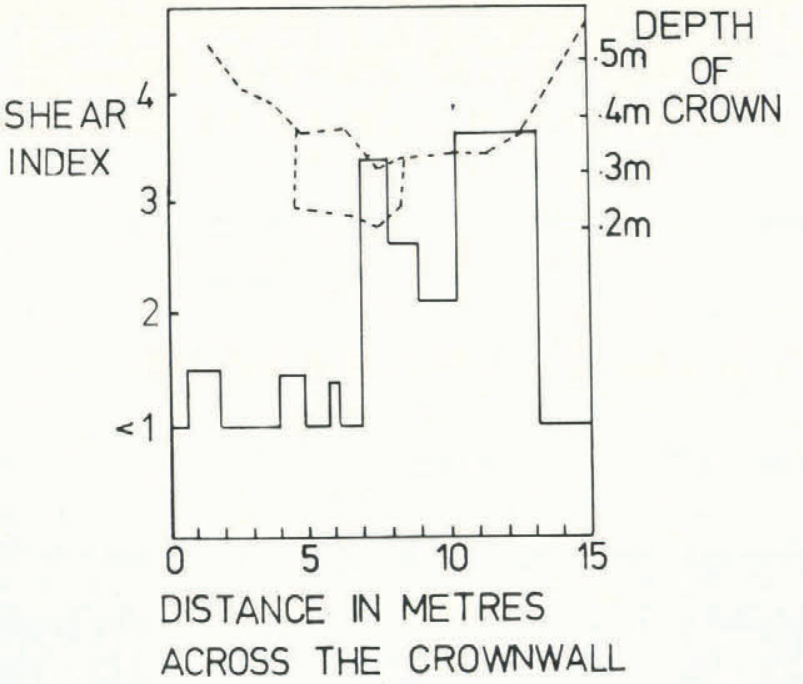

Fig. 4. Fracture depth and basal shear index across the crown wall of a fracture on the cornice wall, 13 July 1982. Average slab density: $140 \mathrm{~kg} / \mathrm{m}^{3}$. Bed surface angle: $47^{\circ}$. Sliding layer: very soft, 0.5-1 mm new snow, including columns, capped columns, stellars, needles, and plates at $-8.4^{\circ} \mathrm{C}$. The avalanche was ski-released near the northern flank wall, and the total number of tests made was 18.

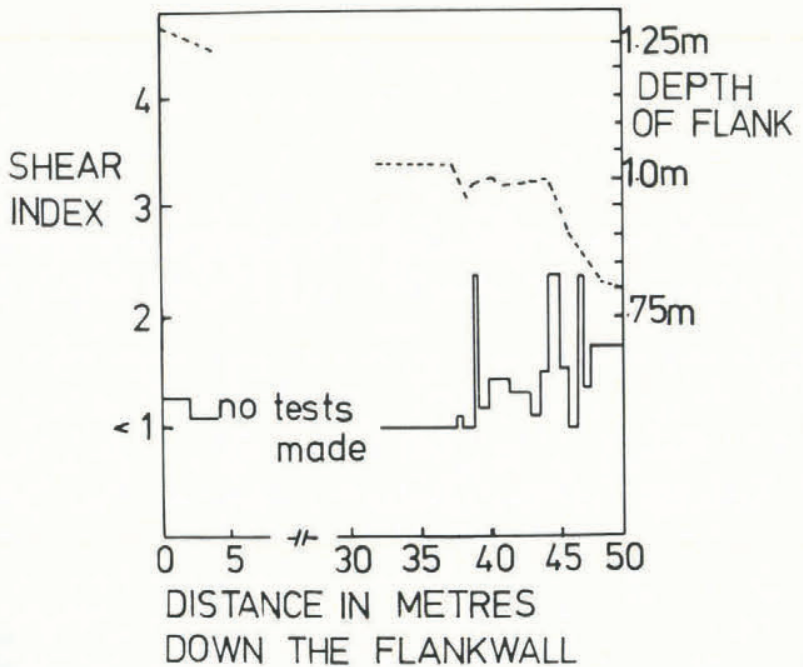

Fig. 5. Fracture depth and basal shear index down a flank wall of a fracture on the cornice wall, 19 September 1982. Average slab density: $290 \mathrm{~kg} / \mathrm{m}^{3}$. Bed surface angle: $30-35^{\circ}$. Sliding layer: $30 \mathrm{~mm}$ of soft $1 \mathrm{~mm}$ faceted crystals (radiation recrystallized) at $-7.0^{\circ} \mathrm{C}$. The avalanche released naturally from new snow loading and the total number of tests made was 23. the northern flank wall, and Figure 4 shows that the fracture propagated across the slope through a pinned zone $(7.5 \mathrm{~m}$ to $13 \mathrm{~m})$, into another weak zone. Our shear tests across this crown wall were made at $1 \mathrm{~m}$ spacings and covered the entire width of the avalanche. The avalanche was classified as a soft slab (slab density of $140 \mathrm{~kg} / \mathrm{m}^{3}$ ) and had sheared within a very soft layer of new snow.

The fracture of 19 September 1982 released naturally, sliding on a layer of buried faceted crystals (radiation recrystallized snow that had been buried by a new snow-fall). Shear measurements were made down parts of the northern flank wall of this avalanche (lack of time prevented us from covering the whole fracture flank). Distances between measurements could be as small as $0.5 \mathrm{~m}$, but often they were spaced further apart.

\section{DISCUSSION}

The average number of shear-strength measurements made on each fracture in thi's study was about twelve, and distances between measurements varied from $0.5 \mathrm{~m}$ to $10 \mathrm{~m}$. On non-fractured slopes which had higher values of $\alpha$, fewer measurements and a lower frequency of tests were made, unless we found a low value of $\alpha(\alpha<2.0)$. In these instances, the tests were clustered around that area to determine the extent of the weakness.

On avalanched slopes, we tried to make the measurements soon after the event to minimize effects of metamorphism of the snow. Although this was not possible at all times, most tests were made within $24 \mathrm{~h}$ of the event. The cold snow temperatures typical of the area (generally less than $-5^{\circ} \mathrm{C}$ at the shear layer), also would inhibit sintering.

We suspect that our measurements of the shear index $\alpha$ could be in error by up to $20 \%$. Most of this error originated in the measurements of the gravitational force down the slope, but other errors arose from measurements of the shear area, and the extra force required to fracture the sample.

By measuring shear strengths at closely similar stress rates (test times of 0 to $5 \mathrm{~s}$ to failure), we hoped to avoid major variations within our measurements due to rate effects. McClung (1977) and de Montmollin (1982) showed that shear strengths depend strongly on test rates and their results suggest that our shear tests would be within the "brittle" range.

Not all the variability in the shear index can be attributed to experimental accuracy. Some of the columns failed before they could be completely isolated from tensile, compressive, and side-shear support, while columns just $0.5 \mathrm{~m}$ away required up to $1500 \mathrm{~N} / \mathrm{m}^{2}$ extra shear stress in the down-slope direction (an increase of $\alpha$ by about $300 \%$ ). In view of this, we have accepted that much of the measured strength variability was due to actual variability of snow properties at the shear layer.

Sommerfeld and King (1979) and Sommerfeld (1980) have proposed that much of the variability and high values of the shear indices may be due to the sample size. They used Daniels (1945) parallel-element theory to provide an explanation of the size and stress relationships of snow in limited areas to those over unlimited areas, and suggested a strength ratio of 0.81 for an area ratio of $\infty: 0.1 \mathrm{~m}^{2}$. The measurements of the shear index described in this paper have not been modified by this ratio.

If we regard the local shear index $\alpha$ as a random variable, we can plot a probability-density function of the index, and the risk of local shear failure (ignoring other means of support) is, by definition, the probability that the actual factor of safety will be less than one. For slopes in our study that had avalanched, the average probability of shear failure determined in this manner was about $33 \%$, and for nonfailed slopes about $12 \%$. These results compare with 
the data from Perla (1977) where he summarized, for 80 avalanches, the mean and standard deviations of $\alpha$ to be 1.66 and 0.98 respectively, which indicates a failure probability of about $25 \%$. Vanmarcke (1977) dealt with earth slope-stability problems using a three-dimensional probability model. He considered the spatial variability of shear strengths and a characteristic correlation distance for the shear strengths. Adjustments to his model could also be made to consider slow variations of average shear strength, which may be useful for considering sintering or weakening processes in a basal layer.

The two examples in Figures 4 and 5 showing basal shear-index variation along extended distances suggest that the shear index $\alpha$ may not be distributed about a single maximum (especially in Figure 4 where data were collected across a crown wall), and so a straight-forward statistical approach may be deceptive.

The examples also show that even though the slope had failed, pinning areas (with local basal shear strength greater than the gravitational shear stress) occurred over about $45 \%$ of the total area tested. This suggests that the mean index may not be as critical as the smallest index, and the size of the zone over which it is smali (the shear deficit area), when assessing a slope stability. Figure 3 suggests that if any zones of weakness $(\alpha<1)$ are detected with a minimum number of tests, then the slope should be considered unstable.

We investigated the critical size of the shear deficit $\left(2 x_{c}\right)$ by considering the tensile strengths of the slabs and making a calculation using Equation (5). Tensile-strength measurements of slabs above weak layers were not made on all the slopes studied, but the tests made are listed in Table I. We suspect errors in the calculated tensile strengths of up to $20 \%$ due to errors in measuring the down-slope gravity force, the extra force required to fracture the sample, and the tensile fracture area. The variation in times to failure in our test ( $2 \mathrm{~s}$ to $15 \mathrm{~s}$ ) are in the brittle range of tests suggested by Narita (1980) and again we infer that the error due to different rates between our tests would not have a large effect on the yield strength $\sigma$ that we have estimated.

The calculation of $2 x_{c} 1$ isted in Table I shows values small compared with the full slab length $\left(2 x_{c}=0.34 \mathrm{~m}\right.$ to $\left.21 \mathrm{~m}\right)$. In most cases where we had made shear tests over extended distances, the lengths of the shear deficit zones were smaller than $2 x_{c}$. This suggests that in most cases, we did not locate the primary fracture area during our limited number of field tests.

We are as yet unclear about the relationship between our measured local indices ( and $2 x_{C}$ ) and the prediction of total slab failure. Boundary conditions and geometric effects have been suggested as important by Perla and others (1982). Little is known about the rate of strain during avalanche fractures, and this rate may differ significantly from that during the field tests. Narita (1980) demonstrated a strong dependence of the tensile yield strength on the test rate (yield strengths for ductile failures were up to $40 \%$ higher than yield strengths for brittle failures). McClung (1979), showed that some snow strain-softened during shear, depending on the snow type and rate of shear. Some snows also exhibited a residual shear strength of only half that of the peak shear strength. Furthermore, our calculations do not consider support from side shear (and also partial basal pinning when calculating $\left.2 x_{C}\right)$.

Despite these uncertainties in interpretation of the tests, from a purely empirical point of view, there is one basis for a practical assessment of slope stability. As shown in Figure 3 , we found a basal deficit with at least one test on each slope that had avalanched. We also note that, in most cases, we had located this deficit with less than ten tests, although on large slopes more than ten tests may be required to locate a pocket of weakness (see Fig. 3 ). It is interesting to note that (from Table I) in four surface snows where low tensile strengths ( 80 to $370 \mathrm{~N} / \mathrm{m}$ ) combined with low shear strengths (10 to $380 \mathrm{~N} / \mathrm{m}$ ) were measured, loose avalanches occurred on nearby slopes. Perla (1980) mentions that this sort of avalanche starts in loose cohesionless surface layers and these measurements support this concept.

We think that the variations of strength of the shear layer often originate from local air-flow patterns during deposition of snow. The deposited snow itself often shows significant local variation in its bulk properties, especially that property sensitive to texture (permeability). We recorded air permeability variations of up to $300 \%$ in otherwise closely similar new snow which had been deposited by wind down a slope (Conway and Abrahamson, 1984).

Bagnold (1941) observed drifts of sand caused by wind channelling through irregularities in a cliff top. Depending on the wind direction and the shape of the cliff top, drifting was more concentrated in some places than others. He described the formation of longitudinal (down the slope) dunes from the lee eddies. Tabler (1980) summarized such drift observations behind snow fences, and found that the lee drift geometry was characterized by a length proportional to the fence height $H$, and a cross-sectional area proportional to $H$. He also noted an increase in snow density behind the fence (due to increased densification with snow depth). These observations may be applicable to variations in geometry at ridge tops, and a complex series of drift distributions could be expected behind an irregular-shaped ridge crest (see Fig. 6).

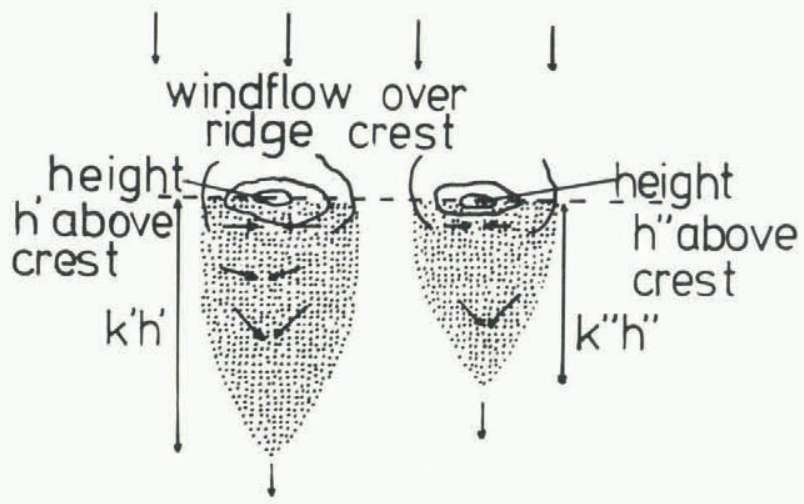

Fig. 6. Longitudinal drift patterns behind an idealized crest showing formation of drift bands across a slope (similar to Tabler's (1980) drift behind snow fences). The arrows indicate local air velocities.

Bagnold (1941) also observed transverse ripples or dunes-normal to the local wind direction, and suggested that these may have a periodic distribution or may be short and irregular (depending on the particle density of the transported medium). Dyunin (1967) and Kobayashi (1979) recorded periodic fluctuations of snow transport rates (thought to be due to turbulence) and suggested that these may be associated with rippling or duning of depositing snow.

We argue below that these two types of deposition large longitudinal drifting and small-scale duning may be superimposed on some slopes, and may account for observed snow property patterns. In particular, our measurements across the crown wall of an avalanche ( $\mathrm{Fig} .4$ ) show an uneven distribution of snow depth above the bed surface which appears to have been caused by large-scale drifting past the irregularities in the ridge crest. The uneven distribution of the drifting snow would not only change the gravitational loading at the shear layer, but also may have affected the properties of the shear layer as it was being deposited. For example, in Figure 4, if the drifting 
proportions across the ridge were similar for the deposition of the weak layer and the deposition of the slab, we would expect the weak-layer thickness to vary across a slope in similar proportions to the slab thickness. The thickness of the weak layer may have a strong influence on the shear strength (this is dealt with later in this discussion). Whatever the mechanism, the step change in shear index shown in Figure 4 (10cated between 7 and $13 \mathrm{~m}$ ) being a change over a larger scale, is likely to be a step change across one of these longitudinal lee drifts.

The characteristics of the $\alpha$ distribution on the southern side of the crown wall (Fig. 4) and down the flank wall of an avalanche (Fig. 5) show fluctuations of much smaller period. These fluctions of strength can be related to the irregular transverse-type ripple described by Bagnold (1941) and in Figure 4, these appear to be superimposed on the weak zone created behind the ridge crest. On the slopes described in Figure 5, we did not find large areas of high $\alpha$, which suggests we were sampling in a relatively weak band up the slope with irregular duning causing irregular shear variations.

Bridgewater (1980) determined the minimum width of a failure zone in hard particulate powders, by describing the shearing surface roughness in terms of particle size. In this way, he estimated a minimum shearing zone about ten particle diameters in thickness within a much thicker particle layer. In many of the shear layers we observed, the thickness of the weak layer was less than ten particle diameters. Although Bridgewater's approach may not be strictly applicable to crystals that can deform, we expect for these thin shear layers that the surface roughness of the stronger adjacent layers will intrude into the shearing zone. The shear strength can then be expected to be sensitively dependent on the local thickness of the weak layer. Both the streaming drifting and the irregular or regular duning above could cause variations in this thickness, and hence variations in shear strength.

McClung (1977, 1979) has suggested strainsoftening as a possibility for basal weakening and progressive failure of some slabs. If a deficit zone is such that it can cause local straining in the surrounding snow, then the shear softening in these neighbouring areas may cause progressive failure nould be an effective means of removing pinning areas and linking weak zones under a slab.

Our arguments above support Gubler's (1978) suggestion (for some avalanche releases) of an initial primary shear fracture which could then propagate over a slope. This general mechanism is also supported by field observations of artificially controlled slopes where trigger zones for an avalanche may occur at positions other than the crown wall. How pinning areas and their distribution affect crack propagation needs further study, but our tests suggest that if any basal shear deficit is found, then propagation is likely. Chowdhury and A-Grivas (1982) present a probabilistic model for the progression of shear failure in a soil slope. Although we do not think that the shear layer can be treated as statistically homogeneous (at least in the horizontal direction), this approach may prove useful in different sub-areas of a slope.

\section{CONCLUSIONS}

We measured high variability of the basal shear strength of snow under slabs over small distances $(0.5 \mathrm{~m})$ and so we considered the potential sliding plane for an avalanche to consist of weak basal zones (deficit areas) between zones of higher strength (pinning areas). A local failure would become more likely as the basal shear strength became small, or the area of the deficit became large.

Our measurements so far suggest that the critical length of reduced basal shear strength required to cause a tensile failure in the slab may be small ( $1 \mathrm{~m}$ or less) in many cases. This size is similar to fracture sizes estimated by Sommerfeld and Gubler (1983) who estimated fracture areas of $0.1 \mathrm{~m}$ to $1 \mathrm{~m}$ radius using the frequency spectra of low-frequency acoustic emissions. Because this critical length may be small, we found that the primary concern when assessing slope stability should be to determine whether a basal shear deficit occurs at any position over the slope.

During our field tests over extended areas on unstable slopes, we generally found a deficit shear area within ten tests, but these tests were timeconsuming when covering large areas. A shear test which would enable a user to make a large number of measurements in a short time would be useful for assessing slope stability - especially for large slopes.

Our stability index $\alpha$ does not consider the pining-area distribution in relation to crack propagation after the initial primary fracture, but our measurements to date suggest that a failure may propagate through areas of high strength that are of similar size to the weak areas.

We found, as a general rule, that if (with a limited number of tests) we found an area where the shear index was less than one, then there were other larger areas of deficit and the slope was unstable. Future work may establish the probability of failure given the number of tests and the distribution of the shear indices found.

\section{ACKNOWLEDGEMENTS}

Financial support for the study came from the Department of Lands and Survey (Wellington, New Zealand), University of Canterbury (Christchurch, New Zealand), Mountain Safety Council of New Zealand, and Mt Hutt Ski Company. Mt Cook Airlines Company provided aircraft access to the field area, and the assistance of Mt Cook National Park Staff with the field experiments was invaluable. The New Zealand Meteorological office provided the weather instruments. The Department of Chemical and Process Engineering (University of Canterbury) sponsored the project and helped develop the concepts and test equipment for the project.

\section{REFERENCES}

Bagnold, R.A. 1941. The physics of blown sand and desert dunes. London, Methuen and Co. Ltd.

Bridgewater, J. 1980. On the width of failure zones. Géotechnique (London), Vol. 30, No. 4, p. 533-36.

Brown, C.B., and others. 1972. Si ab avalanching and the state of stress in fallen snow, [by] C.B. Brown, R.J. Evans, and E.R. LaChapelle. Journal of Geophysical Research, Vol. 77, No. 24, p. 570-80. Chowdhury, R.N., and A-Grivas, D. 1982. Probablistic model of progressive failure of slopes. Journal of the Geotechnical Engineering Division, American Society of Civil Engineers, Vol. 108, No. GT6, p. 803-19.

Conway, H., and Abrahamson, J. 1984. Air permeability as a textural indicator of snow. Journal of Glaciolog Vol. 30, No. 106, p. 328-33.

Daniels, H.E. 1945. The statistical theory of the strength of bundles of threads. I. Proceedings of the Royal Society of London, Ser. A, Vol. 183, No. 995, p. 405-35.

Dyunin, A.K. 1967. Fundamentals of the mechanics of snow storms. (In Oura, H., ed. Physics of snow and ice: international conference on low temperature science. . 1966 ....Proceedings, Vol. 1, Pt. 2. [Sapporo], Institute of Low Temperature Science, Hokkaido University, p. 1065-73.

Gubler, H. 1978. An alternate statistical interpretation of the strength of snow. Journal of Glaciology, Vol. 20, No. 83, p. 343-57. 
Kobayashi, S. 1979. Studies on interaction between wind and dry snow surface. Contributions from the Institute of Low Temperature Science, Ser. A, No. 29.

McClung, D.M. 1977. Direct simple shear tests on snow and their relation to slab avalanche formation. Joumal of Glaciology, Vol. 19, No. 81, p. 101-09.

McClung, D.M. 1979. Shear fracture precipitated by strain softening as a mechanism of dry slab ava1 anche release. Journal of Geophysical Research, Vol. 84, No. B7, p. 3519-26.

Montmollin, V. de. 1982. Shear tests on snow explained by fast metamorphism. Journal of Glaciology, Vol. 28, No. 98, p. 187-98.

Narita, H. 1980. Mechanical behaviour and structure of snow under uniaxial tensile stress. Journal of Glaciology, Vol. 26, No. 94, p. 275-82.

Perla, R.I. 1977. Sl ab avalanche measurements. Canadian Geotechnical Journal, Vol. 14, No. 2, p. 206-13.

Perla, R.I. 1980. Avalanche release, motion, and impact. (In Colbeck, S.C., ed. Dynamics of snow and ice masses. New York, etc., Academic Press, p. 397462.)

Perla, R.I., and LaChapelle, E.R. 1970. A theory of snow slab failure. Journal of Geophysical Research, Vo1. 75, No.36, p. 7619-27.

Perla, R.I., and others. 1982. The shear strength index of alpine snow, by R.[I.] Perla, T.M.H. Beck, and T.T. Cheng. Cold Regions Science and Technology,
Vol. 6, No. 1, p. 11-20.

Roch, A. 1966. Les variations de la résistance de la neige. Union de Géodésie et Géophysique Internationale. Association Internationale d'Hydrologie
Scientifique. Commission pour la Neige et la Glace. Division Neige Saisonniëre et Avalanches. Symposium international sur les aspects scientifiques des avalanches de neige, 5-10 avril 1965, Davos, Suisse, p. 86-99. (Publication No. 69 de 1'Association Internationale d'Hydrologie Scientifique.)

Sommerfeld, R.A. 1973. Statistical problems in snow mechanics. U.S. Dept. of Agriculture. Forest Service. General Technical Report RM-3, p. 29-36.

Sommerfeld, R.A. 1980. Statistical models of snow strength. Joumal of Glaciology, Vol. 26, No. 94,
p. 217-23.

Sommerfeld, R.A., and Gubler, H. 1983. Snow avalanches and acoustic emissions. Annals of Giaciology, Vol. 4, p. 271-76.

Sommerfeld, R.A., and King, R.M. 1979. A recommendation for the application of the Roch index for slab avalanche release. Journal of Glaciology, Vol. 22, No. 88 , p. 547-49.

Stuiver, M., and others. 1981. History of the marine ice sheet in West Antarctica during the last glaciation: a working hypothesis, by M. Stuiver, G. H. Denton, T.[J.] Hughes, and J.L. Fastook. (In Denton, G.H., and Hughes, T.J., ed. The last great ice sheets. New York, Wiley-Interscience, p. 319-436.)

Tabler, R.D. 1980. Geometry and density of drifts formed by snow fences. Journal of Glaciology, Vol. 26, No. 94, p. 405-19.

Vanmarcke, E.H. 1977. Earth slope reliability. Journal of the Geotechnical Engineering Division, American Society of Civil Engineers, Vol. 103, No. GT11, Proc. Paper 13365, p. 1247-65. 